\title{
Um hipódromo suburbano: a experiência do Club de Corridas Santa Cruz (Rio de Janeiro — 1912/1918)
}

\author{
Victor Andrade de Melo ${ }^{1 ; *}$ \\ ${ }^{1}$ Universidade Federal do Rio de Janeiro, Rio de Janeiro, Rio de Janeiro, Brasil
}

\section{RESUMO}

Já há um bom número de estudos históricos dedicados a debater as iniciativas esportivas promovidas na região socioeconomicamente privilegiada do Rio de Janeiro. Não há, todavia, muitas investigaçóes sobre o tema no que tange a outras zonas da cidade, especialmente sobre os subúrbios. A melhor compreensão dessas ocorrências pode ajudar a lançar novos olhares tanto sobre a prática quanto sobre o processo de urbanização. Considerando tais observaçóes, este estudo teve por objetivo discutir a experiência do Club de Corridas Santa Cruz, uma sociedade de turfe que se manteve ativa entre os anos de 1912 e 1918. Especificamente, pretende-se abordar os estigmas e problemas operacionais que enfrentou por ter sido fundada numa área periférica. Para alcance do objetivo, como fontes foram utilizados jornais e revistas publicados no período em tela.

Palavras-chave: história do esporte; história do Rio de Janeiro; turfe; Santa Cruz.

\section{A suburban racecourse: the experience of the Club de Corridas Santa Cruz (Rio de Janeiro - 1912/1918)}

\begin{abstract}
Many historical studies have focused on the sporting events promoted in the socioeconomically privileged region of Rio de Janeiro. There is, however, little research on other parts of the city, especially on the suburbs. The understanding of these occurrences can help further understanding on the sport and the process of urbanization. That being said, this study aims to discuss the experience of Club de Corridas Santa Cruz, a turf society that was active between the years of 1912 and 1918. Specifically, it intends to address the stigmas and operational problems that it had to face because it was founded in a peripheral area. Newspapers and magazines published in the period were used in order to fulfill this objective.
\end{abstract}

Keywords: Sport History; Rio de Janeiro History; Turf; Santa Cruz.

DOI: http://dx.doi.org/10.1590/2237-101X02004008

Artigo recebido em 6 de dezembro de 2017 e aceito para publicação em 22 de junho de 2018.

* Professor da Universidade Federal do Rio de Janeiro/Instituto de História, Programa de Pós-graduação em História Comparada/Faculdade de Educação, Programa de Pós-graduação em Educação, Rio de Janeiro/RJ

— Brasil. E-mail: victor.a.melo@uol.com.br. http://orcid.org/0000-0002-1983-1475.

Artigo originário de pesquisa financiada pelo CNPq, Faperj e Ministério do Esporte/Rede Cedes. 


\section{Un hipódromo suburbano: la experiencia del Club de Corridas Santa Cruz (Río de Janeiro - 1912/1918)}

\section{RESUMEN}

Existen ya un buen número de estudios históricos dedicados a debatir las iniciativas deportivas promovidas en la región socioeconómicamente privilegiada de Río de Janeiro. No hay, sin embargo, muchas investigaciones sobre el tema con respecto a otras zonas de la ciudad, especialmente sobre los suburbios. La mejor comprensión de esas ocurrencias puede ayudar a lanzar nuevas miradas, tanto sobre la práctica, así como el proceso de urbanización. Considerando tales observaciones, este estudio tuvo por objetivo discutir la experiencia del Club de Corridas Santa Cruz, una sociedad de turf que se mantuvo activa entre los ańos de 1912 y 1918. Específicamente, se pretende abordar los estigmas y problemas operacionales que enfrentó por haber sido fundada en un área periférica. Para el alcance del objetivo, como fuentes fueron utilizadas periódicos y revistas publicados durante el periodo en análisis.

Palabras clave: Historia del Deporte; Historia de Río de Janeiro; Turf; Santa Cruz.

\section{Introdução}

Como fundador do prado de Santa Cruz, que tem imposto pesados sacrifícios a seus fundadores, e que hoje constitui o centro de diversóes da população local, penso que não se devem matar tantos esforços dispendidos. ${ }^{1}$

No Brasil, assim como em outros países, a consolidação dos esportes teve relação com os diferentes momentos de urbanização, até mesmo pela prática estar fortemente articulada com o forjar de uma cultura citadina, desdobramento da valorização da esfera pública como lócus de experiências, ocorrência que tem como uma das facetas o fortalecimento de um mercado ao redor dos entretenimentos. ${ }^{2}$ No caso do Rio de Janeiro, tal ocorrência é clara. As modalidades foram se conformando e se espraiando pari passu com a expansão da zona urbana e mudanças no perfil de ocupação das distintas regióes. ${ }^{3}$

Em função do dinamismo econômico, do grande afluxo de imigrantes e migrantes e da

\footnotetext{
${ }^{1}$ Honório Pimentel em $O$ Imparcial, 25 dez. 1914, p. 7.

${ }^{2}$ É grande o número de investigações sobre a consolidação do esporte no país. Para um panorama, ver: MELO, Victor Andrade de (Org.). Os sports e as cidades brasileiras: transição dos séculos XIX e XX. Rio de Janeiro: Apicuri/Faperj, 2010.

${ }^{3}$ MELO, Victor Andrade de; PERES, Fabio de Faria. Esporte e modernidade: o caso do Rio de Janeiro uma abordagem panorâmica. In: MELO, Victor Andrade de (Org.). O esporte no cenário Ibero-Americano. Rio de Janeiro: 7 Letras, 2015, p. 53-69.
} 
maior presença de antigos escravos já libertos, na transição dos séculos XIX e XX, aumentou muito o número de habitantes do Rio de Janeiro. Nesse cenário, tornou-se um problema conseguir moradia, algo que se exponenciou em função das intensas reformas urbanas promovidas na regiáo central. ${ }^{4}$

Aproveitando que se aperfeiçoaram as linhas férreas, em processo de implantação desde os anos 1860, uma parte da população mais pobre, bem como dos setores médios do ponto de vista socioeconômico, começou a mais efetivamente ocupar as regióes periféricas, tanto aquelas mais próximas do Centro quanto as mais distantes. A partir de então, o Rio de Janeiro se conformaria conforme sugere Abreu:

O modelo do Rio tende a ser de uma metrópole de núcleo hipertrofiado, concentrador da maioria da renda e dos recursos urbanísticos, cercado por estratos urbanos periféricos cada vez mais carentes de serviços e de infraestrutura à medida que se afastam do núcleo, e servindo de moradia e de local de exercício de algumas outras atividades às grandes massas de baixa renda. ${ }^{5}$

De acordo com esse autor, o Rio de Janeiro se organizou em círculos. No primeiro (núcleo), que vai da Zona Sul até a Tijuca/Vila Isabel, se encontra a população de maior renda, uma melhor condição de urbanidade e qualidade de serviços, grande parte dos postos de trabalho. No segundo (periferia imediata), que vai até Madureira (por um lado) e a Barra (por outro), há alguma condição de urbanidade e serviços, em nível inferior do que o anterior, disponível para um estrato socioeconômico de menor poder aquisitivo. O terceiro (periferia intermediária) corresponderia a atual Zona Oeste, dividida em áreas urbana e rural, local de residência da maioria da população pobre, para a qual urbanidade e serviços oferecidos são significativamente menos eficientes.

Estudos recentes têm ajudado a entender que, mesmo náo sendo equivocada a compreensáo de Abreu, o quadro de evoluçáo urbana do Rio de Janeiro foi mais complexo do ponto de vista socioeconômico e cultural. De toda forma, se construiu um olhar preconceituoso sobre a periferia, sendo o conceito de subúrbio marcado pela ideia de que se trata de uma regiáo menos civilizada, caracterizada por certa desordem e violência. ${ }^{6}$

Já há um bom número de estudos históricos dedicados a discutir as iniciativas esportivas promovidas na regiáo socioeconomicamente privilegiada do Rio de Janeiro. Sabe-se que estavam articuladas com as estratégias de status e distinção dos diferentes grupos sociais, bem como que funcionaram como mecanismo de coesão e solidariedade. ${ }^{7}$ Não há, todavia, mui-

\footnotetext{
${ }^{4}$ ABREU, Maurício de Almeida. A evolução urbana do Rio de Janeiro. Rio de Janeiro: IplanRio/Zahar, 2011.

${ }^{5}$ Ibidem, p. 17.

${ }^{6}$ FERNANDES, Nelson da Nobrega. O rapto ideológico da categoria subúrbio. Rio de Janeiro: UFRJ, 1995; OLIVEIRA, Márcio Piñon de; FERNANDES, Nelson da Nobrega (Org.). 150 anos de subúrbio carioca. Rio de Janeiro: Lamparina/Eduff/Faperj, 2010.

${ }^{7}$ MELO, Victor Andrade de. Cidade sportiva: primórdios do esporte no Rio de Janeiro. Rio de Janeiro: Relume Dumará/Faperj, 2001. Sobre a difusão de experiências de associativismo, ver: FONSECA, Vitor Manoel Marques da. No gozo dos direitos civis: associativismo no Rio de Janeiro, 1903-1916. Niterói: Muiraquitã, 2008.
} 
tas investigaçóes sobre o tema no que tange a outras zonas da cidade, especialmente sobre os subúrbios, à exceção de algumas que se dedicaram a discutir o envolvimento com o futebol, a modalidade que, de fato, mais se espraiou pela cidade. ${ }^{8}$

Estudos como os de Melo, ${ }^{9}$ Santos Junior ${ }^{10}$ e Melo e Santos Junior ${ }^{11}$ demonstram que muito mais ocorreu do ponto de vista esportivo nos subúrbios do Rio de Janeiro. A melhor compreensão dessas ocorrências pode ajudar a lançar novos olhares tanto sobre a prática quanto sobre a história da cidade, inclusive as contradiçóes e conflitos que cercaram o processo de urbanização.

Considerando tais observaçóes, este estudo teve por objetivo discutir a experiência do Club de Corridas Santa Cruz, uma sociedade de turfe que manteve-se ativa entre os anos de 1912 e 1918. ${ }^{12}$ Como foi uma iniciativa mais tardia em relação às outras — na ocasião permaneciam ativos o Jockey Club, instituído em 1868, e o Derby Club, criado em 1885 - e deslocada do ponto de vista geográfico, promovida no bairro mais distante da regiáo central, especificamente pretende-se abordar os estigmas e problemas operacionais que a agremiação enfrentou por ter sido fundada numa zona periférica.

Para alcance do objetivo, como fontes foram utilizados jornais e revistas publicados na cidade. Na análise e interpretação do material consultado, além de considerar as sugestóes de Luca, ${ }^{13}$ dialogou-se com os estudos de Santos Junior, ${ }^{14}$ no que tange à estigmatização das práticas esportivas do subúrbio, e de Santos, ${ }^{15}$ no tocante às estratégias de monopolização observáveis no turfe fluminense, isso é, "o lento processo de concentração de capital em poucos clubes".

No período investigado, a imprensa já tinha o costume de noticiar o turfe há muitas décadas, havendo mesmo um espaço fixo para a modalidade em boa parte dos periódicos. Como os cronistas encararam a experiência de Santa Cruz? Que representaçóes foram forjadas? Como se posicionaram frente às açôes de outras agremiações? Essas são questóes que

\footnotetext{
${ }^{8}$ Para um balanço dos estudos sobre o futebol nos subúrbios, ver: SANTOS JUNIOR, Nei Jorge. A construção do sentimento local: o futebol nos arrabaldes de Andaraí e Bangu (1914-1923). Dissertação (Mestrado em História Comparada) - Programa de Pós-graduação em História Comparada, Universidade Federal do Rio de Janeiro, Rio de Janeiro, 2012.

${ }^{9}$ MELO, Victor Andrade de. Rio esportivo. Rio de Janeiro: Casa da Palavra, 2015.

${ }^{10}$ SANTOS JUNIOR, Nei Jorge. A vida divertida suburbana: representações, identidades e tensões em um arrabalde chamado Bangu (1895-1929). Tese (Doutorado em Lazer) — Programa de Pós-graduação em Estudos de Lazer, Universidade Federal de Minas Gerais, Belo Horizonte, 2017.

${ }^{11}$ MELO, Victor Andrade de; SANTOS JUNIOR, Nei Jorge. O esporte nos arrabaldes do Rio de Janeiro: o cricket em Bangu (1904-1912). Rio de Janeiro, 2017.

${ }^{12} \mathrm{O}$ tema já mereceu algumas breves linhas em: MELO, Victor Andrade de. Rio esportivo, op. cit.; SANTOS JUNIOR, Nei Jorge. O turf suburbano: o Club de Corridas Santa Cruz. História(s) do Sport (blog), Rio de Janeiro, 7 set. 1915. Disponível em: <https://historiadoesporte.wordpress.com/2015/09/07/o-turf-suburbano-o-club-de-corridas-santa-cruz/>. Acesso em: 4 nov. 2017.

${ }^{13}$ LUCA, Tânia Regina de. História dos, nos e por meio dos periódicos. In: PINSKY, Carla Bassanezi (Org.). Fontes históricas. São Paulo: Contexto, 2005, p. 111-153.

${ }^{14}$ SANTOS JUNIOR, Nei Jorge. A construção do sentimento local: o futebol nos arrabaldes de Andaraí e Bangu (1914-1923), op. cit.

${ }^{15}$ SANTOS, João Manuel Casquinha Malaia. Economia do entretenimento: o processo de monopolização do primeiro empreendimento esportivo no Brasil (1850-1930). Economia e Desenvolvimento, Santa Maria, v. 27, n. 1, p. 202-222, jan./jul. 2015, p. 203.
} 
pretendeu-se responder sempre tendo em conta melhor entender a dinâmica citadina.

\section{Turfe, Santa Cruz, associativismo}

O turfe, em alguma medida, se organizou em regiōes periféricas do Rio de Janeiro. As pioneiras corridas de cavalos foram promovidas, nos anos 1820-1840, na Praia de Botafogo, na ocasiáo ainda de difícil alcance. ${ }^{16}$ Já o primeiro e um dos mais longevos hipódromos, o Prado Fluminense, foi construído no bairro de São Francisco Xavier. ${ }^{17}$ Por ali se instalaram várias agremiaçôes, desde o primevo Club de Corridas (1849), passando pelo Jockey Club Fluminense (1854), notadamente o já citado Jockey Club (1868), ${ }^{18}$ que somente em 1926 se transferiu para a atual sede da Lagoa/Gávea.

Já o Prado Itamaraty, hipódromo do Derby Club (1885), foi instalado na região do Maracaná, exatamente onde hoje se localiza o Estádio Mário Filho. Bem próximo, no local atualmente está a Uerj, existia o prado do Turf Club (1889). Não muito longe dali, nas redondezas do antigo Jardim Zoológico, se situava o Club de Corridas de Vila Isabel (1884). Na Chácara da Cruz (atual Praça Afonso Pena/Tijuca), se localizava o Hipódromo Nacional (1889). Havia ainda, em São Cristóvão, o Prado Guarany (1886). ${ }^{19}$

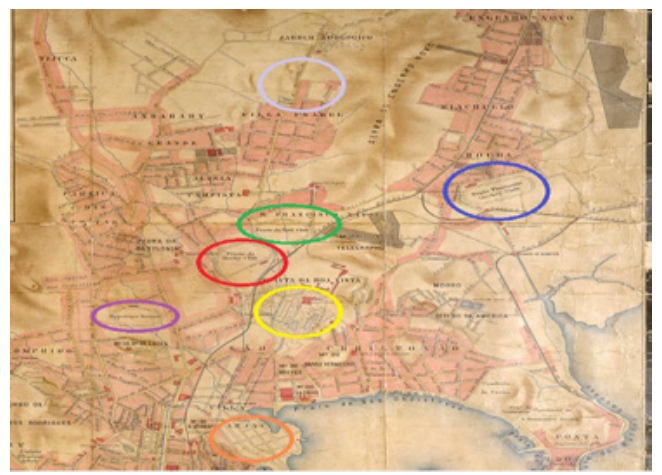

Figura 1. Planta do Rio de Janeiro, 1900. Disponível em:

<http://objdigital.bn.br/objdigital2/acervo_digital/div_cartografia/cart451453/cart451453.jpg>.

Em azul, o Jockey Club. Em cinza, a região onde ficava o clube de Vila Isabel. Em verde, o Turf Club.

Em vermelho, o Derby Club. Em lilás, o Hipódromo Nacional. Em laranja, a região onde se localizava o Prado Guarani. Em amarelo, a Quinta da Boa Vista.

\footnotetext{
${ }^{16}$ MELO, Victor Andrade de. Antes do club: as primeiras experiências esportivas na capital do Império (1825-1851). Projeto História, São Paulo, v. 49, p. 197-236, abr. 2014.

${ }^{17}$ No local, hoje se encontra o Bairro Carioca, conjunto habitacional construído onde fora a Cidade Light.

${ }^{18}$ MELO, Victor Andrade de. O sport em transição: Rio de Janeiro, 1851-1868. Movimento, Porto Alegre, v. 21, n. 2, p. 363-376, 2015; MELO, Victor Andrade de. Entre a elite e o povo: o sport no Rio de Janeiro do século XIX (1851-1857). Tempo, Niterói, v. 20, n. 37, p. 1-22, 2015.

${ }^{19}$ MELO, Victor Andrade de. Rio esportivo, op. cit.; MELO, Victor Andrade de; PERES, Fabio de Faria. Primórdios do esporte no Brasil — Rio de Janeiro. Manaus: Reggo Ediçōes, 2016.
} 
Se essa regiáo, até certo momento do século XIX, era periférica do ponto de vista geográfico, não o era do ponto de vista socioeconômico, não pendendo sobre ela os estigmas que cercariam os subúrbios na centúria seguinte. ${ }^{20}$ Ainda que por lá morasse gente das camadas populares e estratos médios, destacavam-se as habitaçôes das elites, muitos que ali se instalaram atraídos pela proximidade com a família real/imperial (que vivia na Quinta da Boa Vista).

No século XIX, houve somente um hipódromo localizado efetivamente numa regiáo mais afastada. Em 1899, fundou-se, na Penha, o Steeple-Chase Rural Club, dedicado à equitação. Chegou a contar com apoio da imprensa, mas deixou a desejar na organização dos eventos e náo teve vida longa. ${ }^{21}$

Assim sendo, no sentido de subúrbio que apontamos na introdução, foi única a experiência do clube de Santa Cruz, ${ }^{22}$ localidade importante na história do Rio de Janeiro. Um engenho de açúcar por lá existia já em 1567. Os jesuítas fundaram, em 1656, a Fazenda Santa Cruz, de grande extensão, extrapolando mesmo os limites do município do Rio de Janeiro. Segundo Fridman, a região "constituía-se em um grande centro agrário-fabril, autônomo, cujo excedente era escoado por caminhos (estradas, valas, canais e rios navegáveis) tanto em direção ao mar para chegar à Corte, quanto para os outros engenhos das redondezas". ${ }^{23}$

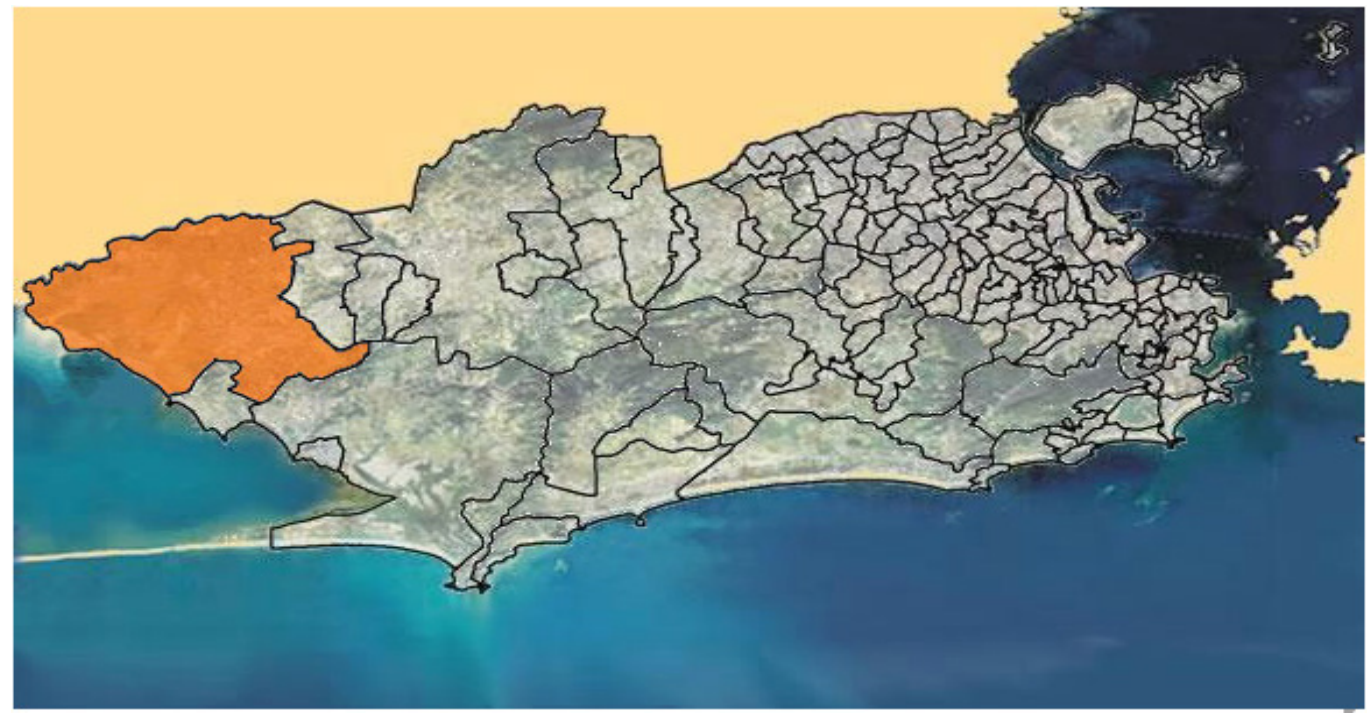

Figura 2. Mapa do Rio de Janeiro, 2017. Disponível em:

<http://portalgeo.rio.rj.gov.br/armazenzinho/web/BairrosCariocas/index2_bairro.htm>. Em destaque, o bairro de Santa Cruz, cujas fronteiras foram definidas nos anos 1830.

\footnotetext{
${ }^{20}$ ABREU, Maurício de Almeida. A evolução urbana do Rio de Janeiro, op. cit.

${ }^{21}$ MELO, Victor Andrade de. Cidade sportiva: primórdios do esporte no Rio de Janeiro, op. cit.

${ }^{22} \mathrm{Na}$ década de 1960, houve uma breve tentativa de implantar um prado na Ilha do Governador, onde hoje se localiza o Estádio da Portuguesa, atualmente alugado para o Flamengo.

${ }^{23}$ FRIDMAN, Fania. De cháo religioso a terra privada: o caso da Fazenda de Santa Cruz. Cadernos IPPUR/ UFRJ, Rio de Janeiro, v. 16, n. 1, p. 311-343, 2002, p. 315.
} 
Quando os jesuítas foram expulsos do Brasil, em 1759, a Fazenda Santa Cruz foi incorporada ao patrimônio da Coroa. ${ }^{24}$ Manteve-se a vocaçáo agrícola e fabril da região, ainda que a pujança econômica tenha se reduzido em função de conflitos de terra. ${ }^{25}$ Já ocupada por foreiros, sesmeiros, posseiros, a área tornou-se mais valorizada com a chegada da família real portuguesa (1808), que se tornou frequentadora da sua propriedade.

A partir de entâo, percebe-se a melhor conformação de um núcleo urbano, majoritariamente habitado pelos empregados que serviam aos monarcas. ${ }^{26}$ Logo surgiram tabernas, casas de pasto e hospedarias, infraestrutura que também serviu a tropeiros e comerciantes que transitavam do centro ao interior (e vice-versa). ${ }^{27}$

Esse núcleo urbano foi se consolidando conforme a regiáo passou a acolher algumas iniciativas industriais, especialmente têxteis, mas também de couro, olarias, entre outras. Em 1881, transferiu-se para Santa Cruz o Matadouro que, desde 1853, ficava na área da atual Praça da Bandeira. A essa altura, o bairro já era servido pela linha férrea — sua estação fora inaugurada em 1878. Assim sendo, há que se ter em conta o que observa Fridman:

O curato de Santa Cruz já mostrava, entre 1885 e 1892, claros indicadores de urbanizaçáo pois os logradouros públicos estavam devidamente delimitados, já havia uma rua do Comércio e serviços de abastecimento de água, além do transporte ferroviário e de bondes. Havia a rua do Encanamento cruzando com a rua da Caixa d'Água, o "centro" definido pela presença do Palácio Imperial, da Praça da Coroa, dos equipamentos públicos e das senzalas. (...). Nestas duas décadas (1880-1890), o crescimento populacional em Santa Cruz atingiu mais de 200\%, percentual justificado pela decisão do governo, em 1886, de estimular a imigração voltada para a produção agrícola na zona oeste da cidade. ${ }^{28}$

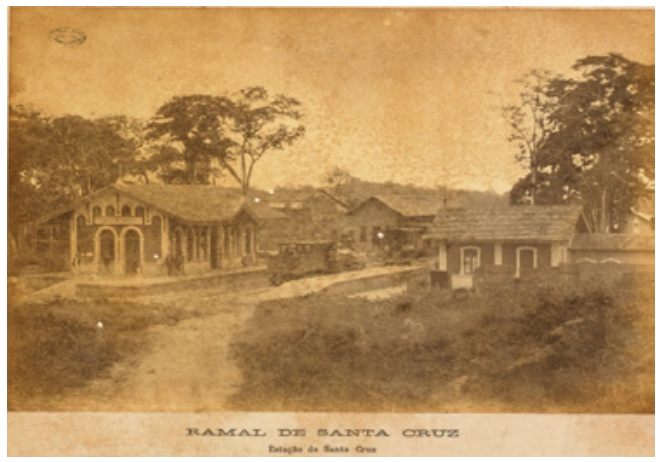

Figura 3. Estaçấo de Santa Cruz, 1881. Disponível em:

<http://objdigital.bn.br/acervo_digital/div_iconografia/icon381909/icon1151181.jpg>.

${ }^{24}$ ENGEMANN, Carlos; AMANTINO, Maria. Santa Cruz: de legado dos jesuítas a pérola da Coroa. Rio de Janeiro: Eduerj, 2013.

${ }^{25}$ FREITAS, Benedicto. Santa Cruz. Fazenda jesuítica, real e imperial. Rio de Janeiro: Asa Artes Gráficas, 1985.

${ }^{26}$ FRIDMAN, Fania. De chão religioso a terra privada: o caso da Fazenda de Santa Cruz, op. cit.

${ }^{27}$ MORAES, Edite. Os donos da Fazenda de Santa Cruz: uma breve história fundiária. In: ANPUH (Org.). Anais do XXIX Simpósio Nacional de História. Brasília: Anpuh, 2017.

${ }^{28}$ FRIDMAN, Fania. De chão religioso a terra privada: o caso da Fazenda de Santa Cruz, op. cit. 
$\mathrm{Na}$ transição dos séculos XIX e XX, intensificou-se a vocação econômica da regiáo, a junção de atividades agrícolas, comerciais e industriais. Habitavam o bairro diversos estratos socioeconômicos, algo que foi marcante no decorrer da história em função da presença de indígenas, escravos, trabalhadores livres, estrangeiros envolvidos com a agricultura, gente das elites - proprietários ou dirigentes tanto ligados à aristocracia quanto aos empreendimentos públicos e privados.

Diversificação de estratos sociais, vitalidade econômica, urbanização, fortalecimento do mercado consumidor - essas são ocorrências que ajudam a entender o delineamento de iniciativas de entretenimento público no bairro. Nos anos 1910, cresceu o número de agremiações. Podemos citar o Rancho Carnavalesco Progresso dos Operários de Santa Cruz, a Sociedade Musical Francisco Braga, o Grêmio Musical 24 de Fevereiro, o Clube Dançante Democratas de Santa Cruz e o Grêmio Democrático de Santa Cruz. ${ }^{29}$ Também foi fundado o Sport Club Santa Cruz. Foi nessa década que surgiu o Club de Corridas Santa Cruz.

\section{Um prado em Santa Cruz}

Em 27 de outubro de 1912, O País, jornal que dedicava grande atenção ao turfe, publicou um programa de seis páreos do Club de Corridas Santa Cruz. ${ }^{30}$ No dia anterior, $O$ Século tinha feito o mesmo, informando que tratava-se da sétima corrida da agremiação. ${ }^{31}$ Nos outros periódicos, encontramos apenas uma referência a provas realizadas no dia $13 .{ }^{32}$

É raro que esses primeiros momentos do clube de Santa Cruz não tenham sido mais amiúde noticiados pelos periódicos. Teria sido uma pequena iniciativa a princípio sem maiores ambiçôes? A instalação de uma agremiação de turfe requisitava certo grau de organizaçáo e investimento, o que torna difícil crer nessa hipótese. A falta de atenção dever-se-ia a tratar-se de uma sociedade do subúrbio? Não há como afirmar peremptoriamente. De toda forma, não conseguimos mais informaçôes sobre esses primórdios da iniciativa. Ao que parece, foram páreos bem modestos.

Em novembro, novas corridas foram promovidas, dessa vez recebendo maior atenção da imprensa. O cronista de O País chegou a publicar um entusiasmado comentário: "Esteve

\footnotetext{
${ }^{29}$ MENDONÇA, Leandro Climaco. Nas margens: experiências de suburbanos com periodismo no Rio de Janeiro, 1880-1920. Dissertação (Mestrado em História) — Programa de Pós-graduação em História, Universidade Federal Fluminense, Niterói, 2011; OLIVEIRA, Igor Estevam Santos de. "E dançaram a noite toda, até a manhá...”: um estudo sobre o funcionamento das sociedades recreativas, carnavalescas e clubes na capital fluminense (1908-1913). Trilhas da História, Três Lagoas, v. 3, n. 5, p. 116-137, jul./dez. 2013; PEREIRA, Juliana da Conceição. A presença feminina nas associaçôes recreativas cariocas (1900-1910). In: ANPUH (Org.). Anais do XXIX Simpósio Nacional de História. Brasília: Anpuh, 2017.

${ }^{30}$ O Pais, 27 out. 1912, p. 9.

${ }^{31}$ O Século, 26 out. 1912 , p. 4.

${ }^{32}$ Jornal do Brasil, 15 out. 1912, p. 10.
} 
muito animada e brilhantemente concorrida a reuniáo levada a efeito, anteontem, no prado de Santa Cruz, um centro de hipismo que progride com uma rapidez assombrosa." 33

O mais interessante é perceber que, talvez inspirada no exemplo de outro clube que surgira no início de 1912, o Friburgo Jockey-Club, a sociedade de Santa Cruz pretendia também oferecer páreos entre janeiro e março, meses em que as agremiaçóes turfísticas mais antigas - Jockey Club e Derby Club — não tinham atividade. Um cronista celebrou a autorização para tal concedida pelo Conselho Municipal: "Sempre é mais perto do que Friburgo, e por isso muito agradará aos apaixonados turfmen." ${ }^{4}$

Posteriormente, decidir-se-ia manter o clube em atividade somente nos meses de verão. Sem ter que disputar o público com as outras agremiaçóes da cidade, a diretoria esperava não só conseguir bons resultados financeiros como também não se chocar com os interesses dos já estabelecidos no campo turfístico.

Essa foi uma das mudanças propostas por uma nova diretoria eleita em dezembro, ${ }^{35}$ tendo como presidente o médico Adelino da Silva Pinto, diretor do Matadouro. Como vice-presidente, assumiu Ernesto Durisch, coronel da Guarda Nacional, fundador da Companhia Agrícola e Pastoril Santa Cruz (dedicada ao cultivo do arroz e à criação de gado), um dos maiores criadores de cavalo do subúrbio. ${ }^{36}$

Entre outros dirigentes, como secretário assumiu Victor Villon, sócio da firma Leal \& Villon, estabelecida no bairro, dedicada ao comércio de vinagres, xaropes e licores. O diretor do prado era Antonio de Moura Costa, funcionário da Fazenda Santa Cruz, onde atuou como cobrador e superintendente. O comerciante de carnes Francisco Martins Costa foi eleito diretor de corridas. Como responsável pelo Stud Book atuava Olympio dos Santos Pimentel, veterinário que possuía grande envolvimento com o Tiro de Santa Cruz. ${ }^{37}$

Como se pode ver, a diretoria era integrada por um misto de importantes personagens locais - dirigentes de empresas públicas e privadas ligadas à agropecuária, comerciantes, profissionais liberais. É provável que esse fosse o perfil de associados do Club de Corridas Santa Cruz, moradores do bairro e das redondezas. Um exemplo, um dos sócios proprietários era Antonio Nominato Leira, proprietário da firma Vianna Nominato. ${ }^{38}$

A iniciativa não se manteria somente com a presença de sócios, era necessário ter em conta outros moradores da região como potenciais frequentadores dos eventos. Em 1912, a cidade tinha 975.818 habitantes, 18.500 viviam em Santa Cruz. ${ }^{39}$ Considerando as re-

\footnotetext{
${ }^{33}$ O Pais, 17 nov. 1912, p. 9.

${ }^{34}$ O Imparcial, 31 dez. 1912, p. 6.

35 O Imparcial, 7 dez. 1912, p. 6.

${ }^{36}$ FRIDMAN, Fania. De chão religioso a terra privada: o caso da Fazenda de Santa Cruz, op. cit.

${ }^{37}$ MENDONÇA, Leandro Climaco. Nas margens: experiências de suburbanos com periodismo no Rio de Janeiro, 1880-1920, op. cit.

${ }^{38} \mathrm{O}$ título de sócio está disponível em: <https://www.facebook.com/AntigoSantaCruz/>. Acesso em: 9 nov. 2017.

${ }^{39}$ População, superfície e densidade territorial do Rio de Janeiro (Distrito Federal) com o crescimento médio anual (1906-1912). Disponível em: <https://seculoxx.ibge.gov.br/populacionais-sociais-politicas-e-culturais/ busca-por-temas/populacao.html>. Acesso em: 6 nov. 2017.
} 
dondezas - Campo Grande e Guaratiba - pode-se contar mais 59.992. De todo modo, certamente tinha-se em conta atrair gente de outros bairros. A diretoria, a propósito, se empenhou em conseguir:

Um trem especial nos dias de corridas às 6 horas da manhá, para o transporte de animais; um outro especial, para passageiros, às $11 \mathrm{~h} 45$ da manhã, só parando em São Francisco Xavier, o qual chegará à Santa Cruz a $1 \mathrm{~h} 05$ da tarde; um carro especial reservado à imprensa, ligado ao de passageiro; regresso desse mesmo especial às $5 \mathrm{~h} 25 \mathrm{em}$ Santa Cruz, para chegar à Central às 6h10 da tarde. ${ }^{40}$

Entre outros, Paulo de Frontin, diretor da Estrada de Ferro Central do Brasil entre 1910-1914, em muitas ocasióes concedeu apoio à agremiaçáo de Santa Cruz, algo que lhe poderia trazer vários potenciais benefícios: possibilitaria que animais de melhor qualidade pudessem tomar parte nas provas; facilitaria o comparecimento da sempre táo esperada imprensa, fundamental para garantir a divulgação das atividades; permitiria maior afluxo de público, inclusive personagens importantes da cidade, cuja presença era esperada para abrilhantar e legitimar o clube.

Depois de mais duas corridas realizadas no mês de dezembro de 1912, a diretoria começou a executar as mudanças planejadas, sendo a mais importante a reforma da pista e da arquibancada, bem como a construção de uma estrutura para receber os animais que viriam de outros bairros. Além disso, as inscriçóes dos competidores passaram a ser feitas na casa de apostas de Garcia Seabra, um dos líderes do turfe fluminense desde o século XIX. Localizada no Centro, tornava mais fácil a participação dos interessados, bem como a divulgação dos eventos. Era usual que por lá os adeptos procurassem informaçóes sobre os páreos. ${ }^{41}$

Para atrair mais competidores, anunciou-se o aumento da premiaçáo. Um cronista, ao comentar tal decisão, conclamou "os proprietários e entraineurs d'esta capital" a "reconhecer e apreciar os sacrifícios feitos pela novel e futurosa sociedade e que assim, concorram para a formação de um programa que compense esses dedicados esforços". ${ }^{42}$ Oferecer páreos atraentes foi uma das principais metas da nova diretoria.

Por isso, comemorou-se que dois importantes treinadores - Américo de Azevedo e Alberto Teixeira, visitaram e elogiaram as obras do hipódromo, se comprometendo a inscrever cavalos para a prova inaugural. ${ }^{43}$ Celebrou-se ainda que jóqueis conhecidos, como Lourenço Junior e Marcellino Macedo, anunciaram interesse em participar dos páreos de Santa Cruz,

\footnotetext{
${ }^{40}$ O Imparcial, 17 jan. 1913, p. 7.

${ }^{41} \mathrm{O}$ local de inscriçóes foi mudando no decorrer do tempo. Durante muitos anos foram realizadas na sede do Centro dos Cronistas Esportivos, uma das mais influentes associaçôes de jornalistas do Rio de Janeiro.

${ }^{42}$ O Pais, 26 jan. 1913, p. 10.

${ }^{43}$ O Pais, 30 jan. 1913, p. 10.
} 
advertidos de que "o regime adotado (...) sem ser o de violência será entretanto o de rigor" ${ }^{44}$ Preocupava à diretoria os tribofes tão comuns na história do turfe. Desencadeados por erros de árbitros ou trapaças diversas, esses conflitos causavam prejuízos e maculavam as representaçôes civilizadas que se tentava construir ao redor da modalidade. ${ }^{45}$

Como se pode perceber, uma parte da imprensa criou grande expectativa ao redor da inauguração do novo hipódromo, planejada para 9 de fevereiro de 1903. Os comentários registravam o empenho da diretoria e exaltavam os avanços do clube. Enfáticos elogios foram feitos à nova pista, segundo um cronista "bem superior às raias dos prados dessa capital". ${ }^{46}$

Essa simpatia nem sempre era observável no que tange a outras agremiaçóes esportivas do subúrbio. No tocante ao futebol, talvez por ser uma modalidade mais popular, usualmente transpareciam preconceitos e estereótipos. ${ }^{47}$ Há que se ter em conta que, no caso do turfe, os periodistas, em geral aficionados pelo esporte, tinham o manifesto desejo de trabalhar num momento em que pouco ocorria. Além disso, não necessariamente coadunavam com os interesses das agremiaçôes mais antigas, especialmente no que se refere a algumas de suas ações mais restritivas.

Esse entusiasmo de alguns periodistas não era compartilhado por todos do meio turfístico. Havia resistências à iniciativa. Comentou um cronista: "A despeito da grande perseguição movida ao prado de Santa Cruz, estamos certos de que de nada valerão diante da inclinação natural popular carioca por aquele recanto, onde felizmente não se morre ainda de insolação, como já houve quem tivesse a coragem de dizer." ${ }^{38}$

O periodista citou o temor com o calor que se manifestou desde que fora anunciada a realização das corridas nos meses de verão. A diretoria do clube de Santa Cruz chegou a argumentar que o bairro tinha temperaturas mais amenas. $\mathrm{O}$ cronista de $O$ País garantiu que os ventos suavizavam a sensação térmica ${ }^{49} \mathrm{Os}$ agentes do turfe, todavia, seguiram expressando sua apreensão com a saúde dos cavalos e do público. Seria mesmo essa a preocupaçáo central ou tratava-se de alguma forma de preconceito com o subúrbio? Provavelmente, ambos.

Há também que se ter em conta questóes operacionais. Mesmo com todas as promessas de conforto anunciadas pelo clube de Santa Cruz, por que as coudelarias que atuavam no Jockey e no Derby gastariam dinheiro e cansariam os cavalos para disputar prêmios pequenos? Em novembro de 1912, no arrabalde, variaram entre $100 \$$ e $60 \$ 000$. Na ocasiáo, se anunciava que nos páreos do Jockey seriam de $500 \$$ a 2:500\$000..$^{50}$ No decorrer do tempo, mesmo com um aumento da premiação oferecida nas corridas promovidas pela agremiação suburbana, a diferença permaneceria grande.

${ }^{44}$ O Imparcial, 17 jan. 1913 , p. 7.

${ }^{45}$ MELO, Victor Andrade de. Cidade sportiva: primórdios do esporte no Rio de Janeiro, op. cit.

${ }^{46}$ O Pais, 23 jan. 1913, p. 8.

${ }^{47}$ SANTOS JUNIOR, Nei Jorge. A construção do sentimento local: o futebol nos arrabaldes de Andaraí e Bangu (1914-1923), op. cit.

${ }^{48}$ O Imparcial, 31 jan. 1913, p. 6.

${ }^{49}$ O País, 26 jan. 1913, p. 10.

${ }^{50}$ O Pais, 12 nov. 1912, p. 9. 


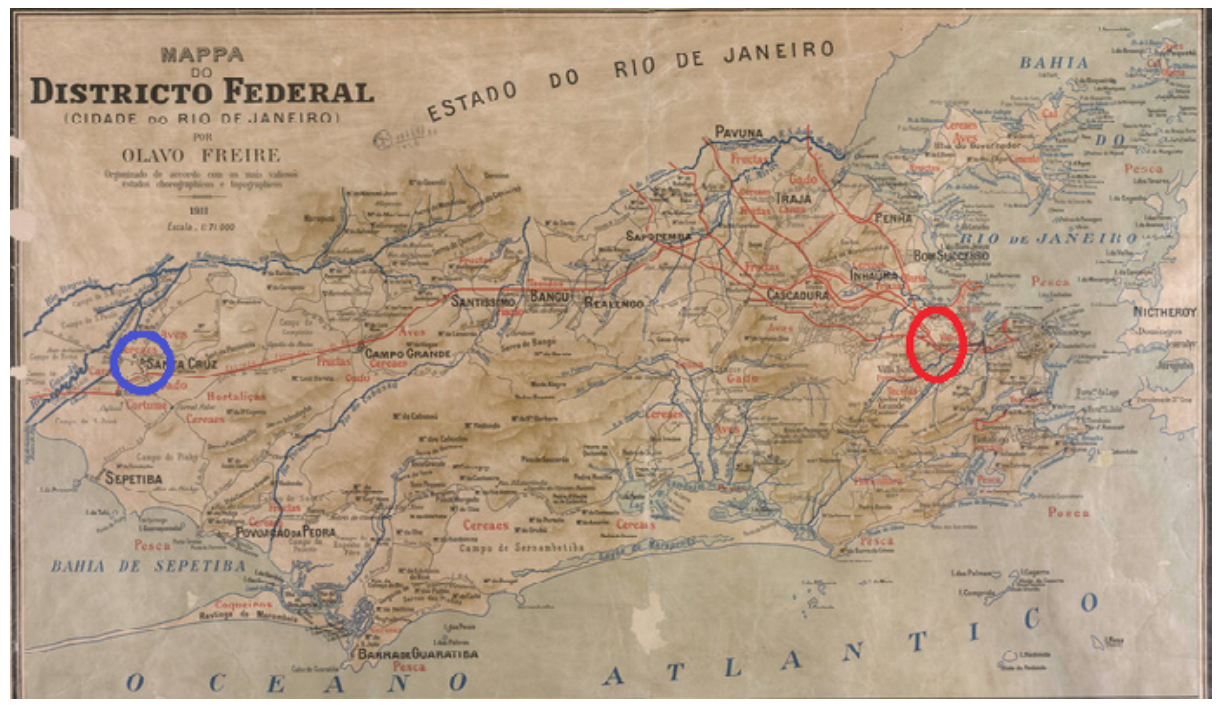

Figura 4. Mapa do Distrito Federal, 1911. Disponível em:

<http://objdigital.bn.br/objdigital2/acervo_digital/div_cartografia/cart177671/cart177671.jpg>.

Para que se tenha uma ideia da distância, em vermelho vemos a área onde se encontravam o

Jockey e o Derby e em azul o local do Club de Corridas Santa Cruz.

Há outro aspecto que se deve ter em conta para entender as ressalvas ao clube suburbano. Em 1912, a média de arrecadaçáo do Jockey foi 139:322\$000, enquanto a do Derby foi 103:443\$000. ${ }^{51}$ Em Santa Cruz, pouco passava dos 3:000\$000, valor que aumentou no decorrer do tempo, mas nunca chegou aos 20:000\$000. Apesar disso, poderia haver alguma preocupação de que a atuação de uma nova sociedade pudesse diminuir os lucros das agremiaçôes mais antigas. Vale ter em conta que o turfe passava por uma crise, uma das maiores de sua trajetória, o que levaria, inclusive, à fusão do Derby e do Jockey em 1932.

Citemos que, em fevereiro de 1912, houve uma polêmica ao redor da ideia de criar uma nova agremiação nos terrenos ainda desocupados do antigo Turf Club. Ao fim, depois de muitas críticas, fracassou a iniciativa. Sugerimos que essas reaçôes eram parte do processo de monopolização das atividades turfísticas, conforme observado por Santos:

No caso do turfe, quanto mais e melhores páreos um clube tivesse, maior era sua chance de atrair mais público em detrimento de outros clubes. Desta maneira, o processo de monopolização da produção e do mercado para as corridas de cavalos acontecia na disputa concorrencial de clube para clube. No caso do Rio de Janeiro, apenas um clube sobreviveu, o Jockey Club, vencendo a concorrência (...) se utilizando de práticas comuns da economia capitalista. ${ }^{52}$

\footnotetext{
${ }^{51}$ O País, 16 jul. 1912 , p. 8.

52 SANTOS, João Manuel Casquinha Malaia. Economia do entretenimento: o processo de monopolização do primeiro empreendimento esportivo no Brasil (1850-1930), op. cit., p. 206.
} 
Vejamos que, no orçamento da prefeitura para 1913, Jockey e Derby foram autorizados cada um a reter até $40 \%$ dos impostos sobre apostas..$^{53}$ Já nos orçamentos de 1914 e 1915, contemplou-se o Club de Corridas Santa Cruz, reduzindo-se para 20\% o valor dos impostos que poderia reter cada uma das três entidades turfísticas. ${ }^{54}$ Como bem percebe Santos: "O Estado, ao oferecer benesses a determinados clubes e ao legislar sobre as diversas organizaçôes que se dedicavam ao entretenimento, também deve ser analisado como agência regulatória do campo." ${ }^{55} \mathrm{O}$ fato relevante é que o surgimento de uma nova agremiação acabou por reduzir um benefício das já existentes.

Por fim, e do mesmo modo importante, não devemos desprezar a existência de preconceitos de status e classe. Lembremos que a agremiação de Santa Cruz era mais conhecida por enviar "pungas" para páreos menos relevantes do Derby e Jockey. A propósito, a diretoria do clube suburbano era integrada por gente da elite local que tinha algum grau de influência na cidade, mas cuja expressão simbólica não se equiparava com aquela dos dirigentes das outras duas sociedades, personalidades como Lineu de Paula Machado e Paulo de Frontin.

Desejava claramente a diretoria de Santa Cruz adotar os mesmos parâmetros de funcionamento das agremiaçóes mais antigas, bem como que o clube fosse reconhecido como parte desse seleto grupo das "fidalgas" sociedades da modalidade. Para tal, entabulou várias estratégias de aproximação. Homenageou-as com nomes de páreos. Concedeu títulos de sócios honorários ao comendador Seabra, a Aguiar Moreira (presidente do Jockey Club) e a Paulo de Frontin, (dirigente máximo do Derby Club). Em várias ocasióes buscou se integrar às atividades turfísticas da cidade, como na entrega da Taça Seabra, um concurso anual de prognósticos promovido entre cronistas esportivos, ocasião em que se celebrava e avaliava a temporada que se encerrara.

Essas açóes não tiveram o êxito esperado. Algumas decisóes tomadas por coudelarias mais relacionadas aos clubes tradicionais dificultaram mesmo a realização das corridas previstas para fevereiro de 1913. Às vésperas, quando o programa já estava confirmado, algumas desistiram de participar. $\mathrm{O}$ cronista de $O$ Imparcial não teve dúvidas, voltando a afirmar que tratava-se de "uma perseguição para a qual náo encontramos razóes". 56

Um novo problema surgiu com o atraso das obras de hipódromo (construído próximo da estação de trem, nas terras de Ernesto Durisch). A diretoria transferiu para março as corridas, declarando não desejar "dar a sua reunião inaugural (...) senão quando o prado estiver em condições de oferecer todo o conforto ao público". ${ }^{57}$

\footnotetext{
${ }^{53}$ Nesse mesmo orçamento, prados e sedes das duas agremiaçóes foram isentos de pagar imposto predial.

${ }^{54}$ Coleçáo de Leis Municipais e vetos — 1897 a 1931.

${ }_{55}$ SANTOS, João Manuel Casquinha Malaia. Economia do entretenimento: o processo de monopolização do primeiro empreendimento esportivo no Brasil (1850-1930), op. cit., p. 205.

${ }^{56}$ O Imparcial, 3 fev. 1913, p. 7.

${ }^{57}$ O Imparcial, 6 fev. 1913, p. 6.
} 


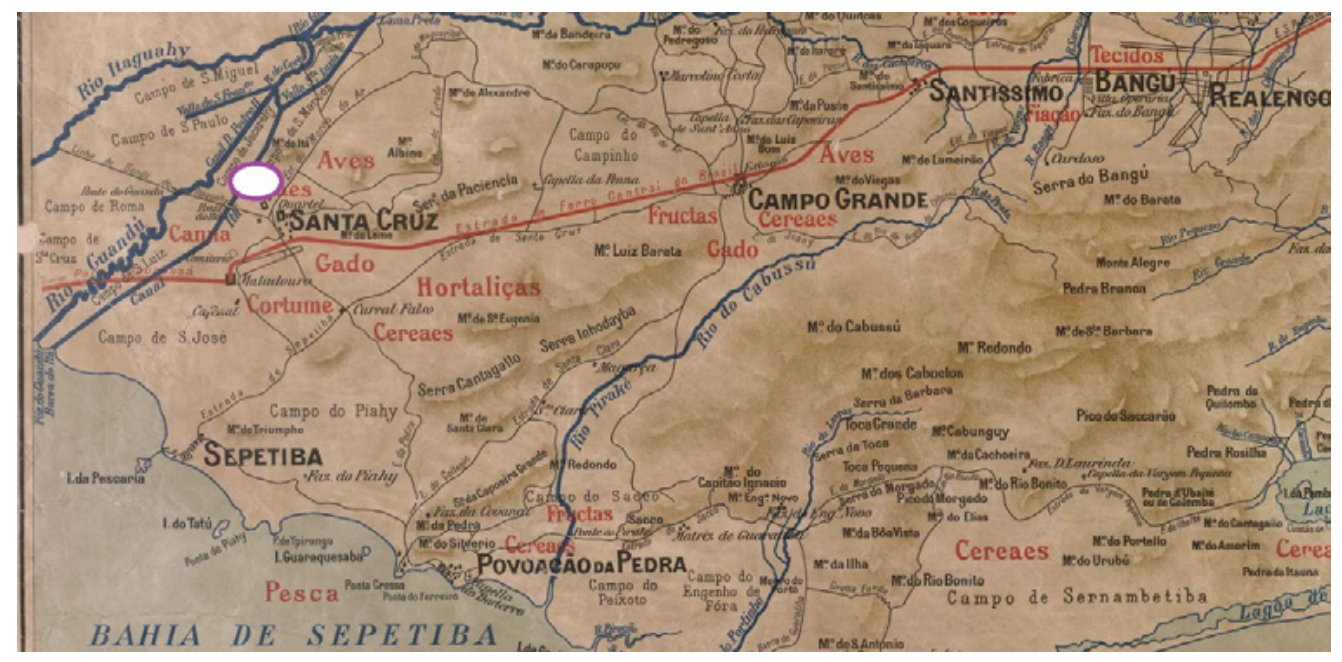

Figura 5. Mapa do Distrito Federal, 1911. Disponível em:

<http://objdigital.bn.br/objdigital2/acervo_digital/div_cartografia/cart177671/cart177671.jpg>.

Em destaque, o local do hipódromo de Santa Cruz.

A atual Rua do Prado lembra a existência da agremiação.

Depois de mais dois adiamentos, superados parcialmente os problemas com a preparação do novo prado e com a composição do programa em função da ausência de animais inscritos, ${ }^{58}$ em 23 de março de 1913 ocorreu a táo esperada e anunciada inauguração da nova pista e arquibancada.

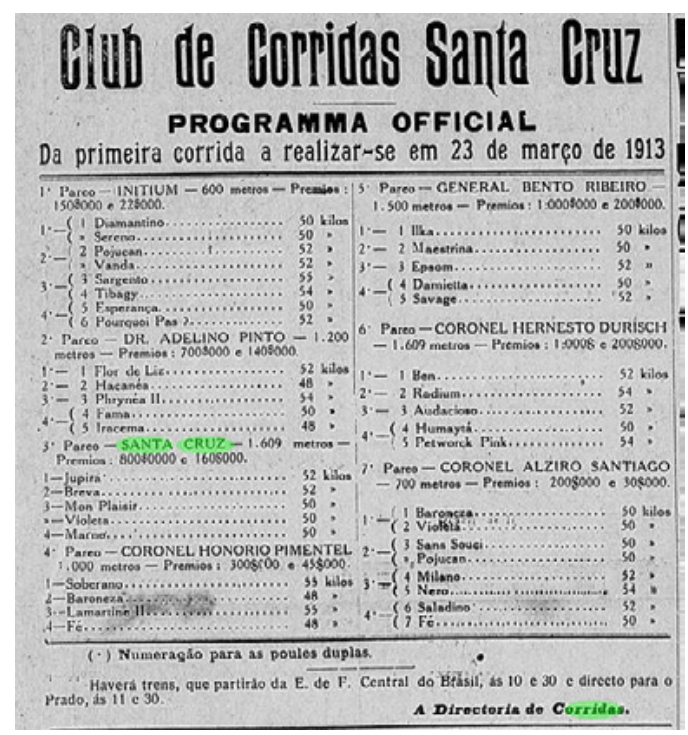

Figura 6. Programa de corridas. O Imparcial, 23 mar. 1913, p. 12.

\footnotetext{
${ }^{58}$ A diretoria chegou a reduzir exigências, diminuir o preço das inscrições e aumentar os prêmios a fim de atrair um maior número de interessados.
} 
Foram organizados sete páreos, três para "peludos" (cavalos de menor qualidade), quatro para "animais de sangue". ${ }^{59}$ Grande parte dos animais era de criados no subúrbio, muitos de propriedades de dirigentes e associados. A despeito dos esforços da diretoria, não era possível esconder a diferença de qualidade com o que ocorria no Jockey e Derby.

$\mathrm{Na}$ verdade, na véspera das corridas inaugurais, alguns cronistas subiram o tom das críticas. Um deles sugeriu que houve desorganização no envio do programa e dos convites. $\mathrm{Na}$ sua avaliação, se assim seguisse, a agremiação iria "prosseguir nas suas corridinhas cabulosas de peludos muito ranhetas" ${ }^{60}$ No seu olhar, seria um evento "à Friburgo", semelhante ao da outra sociedade pouco prestigiada, o oposto do que desejava a diretoria de Santa Cruz.

Esse mesmo cronista reconheceu que o evento foi um sucesso de público, mas registrou as condiçóes deficientes do hipódromo. ${ }^{61}$ Semelhante foi a apreensão do periodista de O Malho. Para ele, se tratou de uma ocasião marcada por "grande brilhantismo", com arquibancadas "repletas" e com boa recepção para os convidados. Não deixou, todavia, de observar que eram necessários "grandes melhoramentos" nas "arquibancadas, casa da poule, botequim, sala para imprensa, etc."62

Dois dados ajudam a ponderar o sucesso do evento - a movimentaçâo de apostas (bem acima da média da agremiação, 9:588\$000) e as imagens da inauguração. Vejamos a capa de O Imparcial (Figura 7). As imagens são contrastantes. Na parte superior, se vê um acidente fatal que houve com uma égua. Uma visão não exatamente positiva. $\mathrm{Na}$ inferior, apresenta-se o hipódromo lotado, uma demonstração de sucesso. De um lado, o bom afluxo de público era um sinal alvissareiro. De outro, náo se verificou o glamour que cercava as atividades do Jockey e do Derby. Essa dubiedade é uma boa expressão da trajetória do prado.

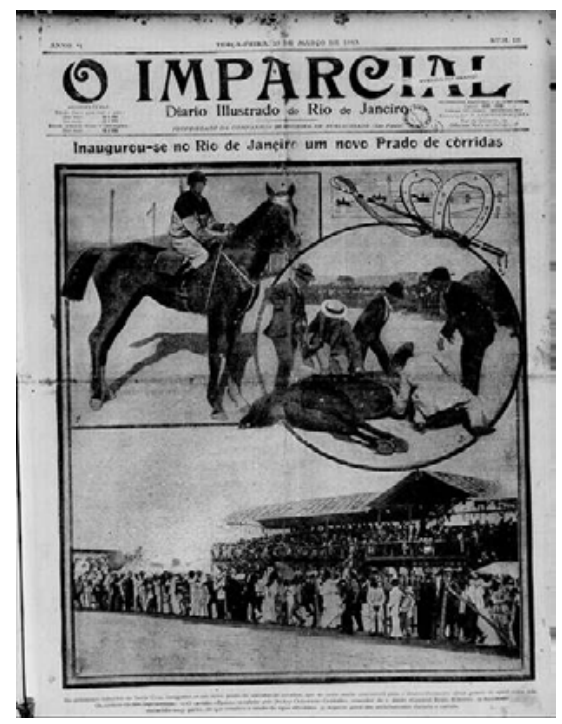

Figura 7. Cenas do evento inaugural do Club de Corridas. O Imparcial, 25 nov. 1913, p. 1.

\footnotetext{
${ }^{59}$ O Imparcial, 19 mar. 1913, p. 6.

${ }^{60}$ O Imparcial, 21 mar. 19013, p. 8.

${ }^{61}$ O Imparcial, 24 mar. 1913, p. 7.

${ }^{62}$ O Malho, 29 mar. 1913, p. 27.
} 
O evento inaugural até contou com a presença de alguns personagens importantes da cidade, inclusive um representante do Jockey Club, Alfredo Santos. Perceba-se que náo foi o presidente da tradicional agremiaçáo que compareceu. De fato, a alta elite do Rio de Janeiro não se deslocou para Santa Cruz.

Enquanto, enfrentando grandes dificuldades, a sociedade de Santa Cruz inaugurou um belo mas simples e ainda precário hipódromo, o Derby Club, mesmo passando por uma crise financeira, lançou a pedra fundamental de seu edifício da Avenida Rio Branco, a ser construído ao lado da sede do Jockey Club. Como isso foi possível? Acesso a crédito. San$\operatorname{tos}^{63}$ lembra que o Jockey foi autorizado a obter um empréstimo de 400:000\$000 para erguer seu prédio. Algo semelhante ocorreu com o Derby. Os dois imóveis são uma expressão do perfil das agremiaçóes.

No decorrer da temporada, o clube de Santa Cruz seguiu enfrentando dificuldades para preparar um programa atrativo, tendo mesmo que adiar algumas corridas em função da ausência de inscrições. Ainda assim, o público foi crescente. Nos páreos de 30 de março, se deu a maior arrecadação até então $(14: 086 \$ 000){ }^{64}$

Mesmo que não fosse suficiente para cobrir os elevados custos de manutenção, a diretoria sentia-se estimulada por esses resultados e pela animação de um setor da imprensa que, a despeito das críticas, apresentava a agremiação como uma destacável novidade: "Vivem nossos turfmen entusiasmados com esse novo prado (...)." ${ }^{\prime 65}$ Com isso, ainda perspectivava que o clube fosse efetivamente aceito no seleto grupo das tradicionais sociedades da modalidade.

\section{Sucessos, conflitos, fracassos}

Para a temporada de 1914, a diretoria considerou cuidadosamente os problemas do ano anterior, se dedicando a aperfeiçoar o funcionamento e conforto do hipódromo, bem como a melhorar a qualidade dos páreos. Essas açóes, junto com a garantia da continuidade da oferta de trens especiais saindo da Central, eram consideradas fundamentais para garantir a viabilidade do clube de Santa Cruz.

No que tange à infraestrutura, os problemas foram em boa medida solucionados. Seguiu, todavia, o desafio de montar bons páreos, já que as melhores coudelarias e os melhores jóqueis continuavam não demonstrando entusiasmo em concorrer no bairro suburbano. De todo modo, em 18 de janeiro foi inaugurada a segunda temporada do "pitoresco prado de corridas Santa Cruz" ${ }^{66}$ Pelo volume de apostas (7:169\$000), parece ter comparecido razoável público.

\footnotetext{
${ }^{63}$ SANTOS, João Manuel Casquinha Malaia. Economia do entretenimento: o processo de monopolização do primeiro empreendimento esportivo no Brasil (1850-1930), op. cit.

${ }^{64}$ O Pais, 1 abr. 1913, p. 9.

${ }^{65}$ O Imparcial, 29 mar. 1913, p. 6.

${ }^{66}$ O Pais, 19 jan. 1914, p. 7.
} 
Mesmo enfrentando restriçóes, o clube logrou bons resultados nessa temporada. Foram promovidas muitas corridas aparentemente bem organizadas, contando com bom público e boa movimentação de apostas. ${ }^{67}$ Os elogios nos jornais se tornaram usuais. Um cronista assim se pronunciou sobre um dos eventos: "A corrida de encerramento levada a efeito ontem (...) teve um brilhantismo além da expectativa quer pelo lado esportivo quer pelo lado social." ${ }^{68}$

Com isso, também surgiram alguns problemas usuais nas outras agremiaçóes, notadamente o que era considerado indisciplina, quebra de regras ou armaçóes de resultados, ocasiôes que, em geral, envolviam os jóqueis (embora esses por vezes seguissem ordens de seus patrôes).

Alguns periódicos foram muito incisivos nas denúncias, deixando transparecer certo preconceito, como se pode ver na posiçáo do cronista de $A$ Rua: "O Club de Santa Cruz encerrou anteontem a série de seus ridículos e monumentais meetings turfistas, nos quais brilharam todos os 'pungas' das cercanias do Matadouro e os mais reverendos 'bacamartes' das coudelarias desta Capital." " ${ }^{69}$ Outros periodistas reconheceram os esforços da diretoria no sentido de coibir as trapaças. Todavia, também observavam que nem sempre foram eficazes tais açóes.

Tais problemas também ocorriam no Derby e no Jockey, até mesmo com jóqueis conhecidos. O tom das matérias, entretanto, sugeria que no clube suburbano se mostravam acentuados. Nesse ponto, a abordagem da imprensa se aproximava do que Santos Junior ${ }^{70}$ chamou a atenção no que tange à cobertura dos jogos de futebol. Os problemas que havia nos "clubes fidalgos" eram atenuados, enquanto os das agremiaçóes do subúrbio eram enfatizados.

Vejamos que essas ocorrências também tinham relação com a menor possibilidade de escolha dos cavalos e jóqueis. Alguns dos que se inscreviam para correr em Santa Cruz não eram aceitos ou tinham problemas com o Jockey e Derby. Isso é, a condição periférica do clube o colocava em dificuldades para resolver e minimizar certos problemas que atingiam a todas as agremiaçóes.

Os tribofes constantes começaram a forjar uma má fama para o prado de Santa Cruz. A diretoria, percebendo o quanto isso poderia prejudicar seus intuitos para a agremiaçáo, para além de costumeiramente punir os responsáveis, contestava publicamente os cronistas, reafirmando seus compromissos com o desenvolvimento do turfe fluminense. Conflitos mais intensos estavam por vir.

Em dezembro de 1914, as diretorias do Jockey e do Derby anunciaram que também promoveriam corridas nos meses de janeiro a março. ${ }^{71}$ Até então, somente o clube de Santa

\footnotetext{
${ }^{67}$ À busca de atrair inscriçóes para poder preparar programas mais emocionantes, a diretoria ofereceu um cronômetro de ouro ao jóquei que conseguisse maior número de vitórias sem ser punido.

${ }^{68}$ A Notícia, 30 e 31 mar. 1914, p. 3.

${ }^{69}$ A Rua, 28 mar. 1915, p. 2.

${ }^{70}$ SANTOS JUNIOR, Nei Jorge. A construção do sentimento local: o futebol nos arrabaldes de Andaraí e Bangu (1914-1923), op. cit.

${ }^{71}$ O Imparcial, 16 dez. 1914, p. 9.
} 
Cruz tinha recebido autorização para tal, sob o argumento de que se encontrava na zona rural. O debate chegou ao Conselho Municipal, avaliando-se de diversos pontos de vista a pertinência de permitir a realização, no verão, de tais eventos numa região mais central da cidade. Os intendentes se dividiram e esgrimiram argumentos divergentes.

Nesse cenário, voltou-se a discutir a pertinência do turfe, seu caráter de jogo de azar, a ação das casas de apostas. A modalidade realmente tinha como compromisso o desenvolvimento da raça de cavalos nacionais - um argumento que marcou sua trajetória desde os primórdios $^{72}$ - ou tratava-se apenas de uma diversão fortuita? Era mesmo um esporte que contribuía com o processo civilizatório ou uma máscara para trapaças que deveriam ser combatidas?

Não surpreende que o clube de Santa Cruz tenha planejado sua primeira exposição de cavalos em janeiro de 1915, uma maneira de deixar claro que estava empenhado em contribuir com a economia nacional. A ocasião contou inclusive com a visita de um enviado do Ministério da Agricultura. Foi oferecido um farto almoço aos representantes governamentais, às lideranças locais e às personalidades do turfe. Os discursos proferidos reiteraram os supostos compromissos da diretoria com o progresso do país. ${ }^{73}$

Por que as agremiaçóes antigas tomaram a decisão de promover corridas nos meses de verão? Segundo anunciado, por interesse dos proprietários. Talvez tenham percebido que estava muito caro enviar seus animais para São Paulo (havia relaçôes com o Jockey Club paulistano, que promovia páreos entre janeiro e março). Ceder os cavalos para Santa Cruz ou Friburgo não era uma opção bem-vista.

Além disso, reduzir-se-ia a possibilidade de funcionamento da nova agremiação, reforçando a posição de exclusividade do Derby e do Jockey. Os proprietários estavam de olho nos prêmios; as agremiaçóes, na arrecadação das apostas. Como lembra Santos, o caráter de jogo "nos pode revelar dois aspectos relevantes da organização destes eventos como açóes de comercialização de serviços de entretenimento e de impulsão a uma mentalidade capitalista" ${ }^{74}$ Para esse autor, concentração e centralização de capital eram indicadores do processo de monopolização entabulado pelas sociedades mais tradicionais.

O prado de Santa Cruz tornou-se o centro do debate. Se esta agremiaçáo podia organizar atividades entre janeiro e março, por que isso não seria permitido para as outras? A diretoria do clube do arrabalde chegou a publicamente desmentir que estava sendo beneficiada no que tange aos impostos, tampouco que estava por trás das iniciativas de manter a proibição. ${ }^{75}$

\footnotetext{
${ }^{72}$ SANTOS, João Manuel Casquinha Malaia; GIGLIO, Sérgio Settani. O papel da memória na construção da identidade organizacional: a Sociedade Jockey Club (1868-1932) e o "desenvolvimento da riqueza pastoril”. Recorde: Revista de História do Esporte, Rio de Janeiro, v. 10, n. 1, p. 1-21, jan./jun. 2017.

${ }^{73}$ Correio da Noite, 18 jan. 1915, p. 4.

${ }^{74}$ SANTOS, João Manuel Casquinha Malaia. Economia do entretenimento: o processo de monopolização do primeiro empreendimento esportivo no Brasil (1850-1930), op. cit., p. 212.

75 O Século, 19 dez. 1914, p. 2.
} 
Mas alguns depoentes ligados ao subúrbio foram explícitos: autorizar o Jockey e o Derby a promoverem corridas nos meses de verão significaria o fim da outra sociedade. ${ }^{76}$

Por sua capacidade de influência, o mais esperado é que seriam beneficiados os "clubes fidalgos". Todavia, houve o oposto. Graças à atuação de intendentes que tinham relação com o clube de Santa Cruz, entre os quais e especialmente Honório Pimentel - um dos fundadores da agremiaçáo do arrabalde e relator do orçamento de $1915^{77}$ —, não foi estendido ao Derby e ao Jockey o direito de organizar provas entre janeiro a março. Tal decisão ocasionou revolta em alguns setores do turfe. Um dos desdobramentos foi o aumento do preconceito com a sociedade suburbana.

O posicionamento de José Justo é uma expressão dessa insatisfação. ${ }^{78}$ Tratou-se, no seu olhar, de atender o interesse particular de alguns intendentes, beneficiando um prado em detrimento dos outros. Sugeriu que o Jockey Club poderia reagir cumprindo à risca seu código de corridas, proibindo a participação em seus páreos de cavalos que corressem em Santa Cruz.

Isso ocorrera antes na história do turfe fluminense, na transição das décadas de 1880/1890, com o Prado Guarani, hipódromo que se diferenciava por seu caráter mais popular. Por lá funcionaram algumas agremiaçóes de curta duraçáo. Tudo se fez para combater suas atividades, inclusive a proibição de circulação de animais, ${ }^{79}$ a mesma que se ameaçava adotar com o Club de Corridas Santa Cruz.

A antipatia de alguns se exponenciou no início de 1915 por uma decisão da diretoria de Santa Cruz. A agremiaçáo marcou sua atividade inaugural para o mesmo dia da entrega da Taça Seabra, uma das ocasióes mais festejadas do turfe fluminense. Para o cronista de $O$ País, tratava-se de uma desconsideração com a imprensa, que não poderia se fazer presente por estar envolvida com o festejo. Náo deixou de ironizar que o prado do subúrbio se celebrizou "pela série enorme de circunstâncias que obrigaram o público a se esquivar de frequentar o hipódromo". 80

Uma vez mais, a diretoria do Club de Corridas publicou uma contestaçáo do ponto de vista do cronista, que assim reagiu: "O Derby Club e o Jockey Club, duas sociedades já feitas e já enriquecidas, indubitavelmente as duas únicas verdadeiras sociedades do turfe carioca, não se amuaram ainda conosco porque censuramos algum ato seu." ${ }^{" 1}$ Mesmo que também elogiasse, a imprensa usualmente hierarquizava, comparava com demérito da agremiação suburbana. Por vezes, o menosprezo era explícito: "O turfe, entre nós, está em férias, ao momento. O prado de Santa Cruz não satisfaz, por todos os títulos." ${ }^{2}$

\footnotetext{
${ }^{76}$ O Imparcial, 25 dez. 1914, p. 7.

${ }^{77}$ Foi intendente entre os anos de 1904 e 1919 e deputado federal entre 1921 e 1923. Foi uma das mais conhecidas lideranças políticas de Santa Cruz e dos subúrbios. Para mais informaçóes, ver: SOUZA, Antonio Nascimento. Memória e história política de Santa Cruz. Rio de Janeiro: Instituto Municipal de Arte e Cultura - Rio Arte, 2005.

${ }^{78}$ A Noite, 29 dez. 1914, p. 5.

${ }^{79}$ MELO, Victor Andrade de. Cidade sportiva: primórdios do esporte no Rio de Janeiro, op. cit.

${ }^{80}$ O Pais, 4 jan. 1915, p. 5.

${ }^{81} O$ País, 6 jan. 1915, p. 6.

${ }^{82}$ Ilustração Brasileira, 16 fev. 1915, p. 83.
} 


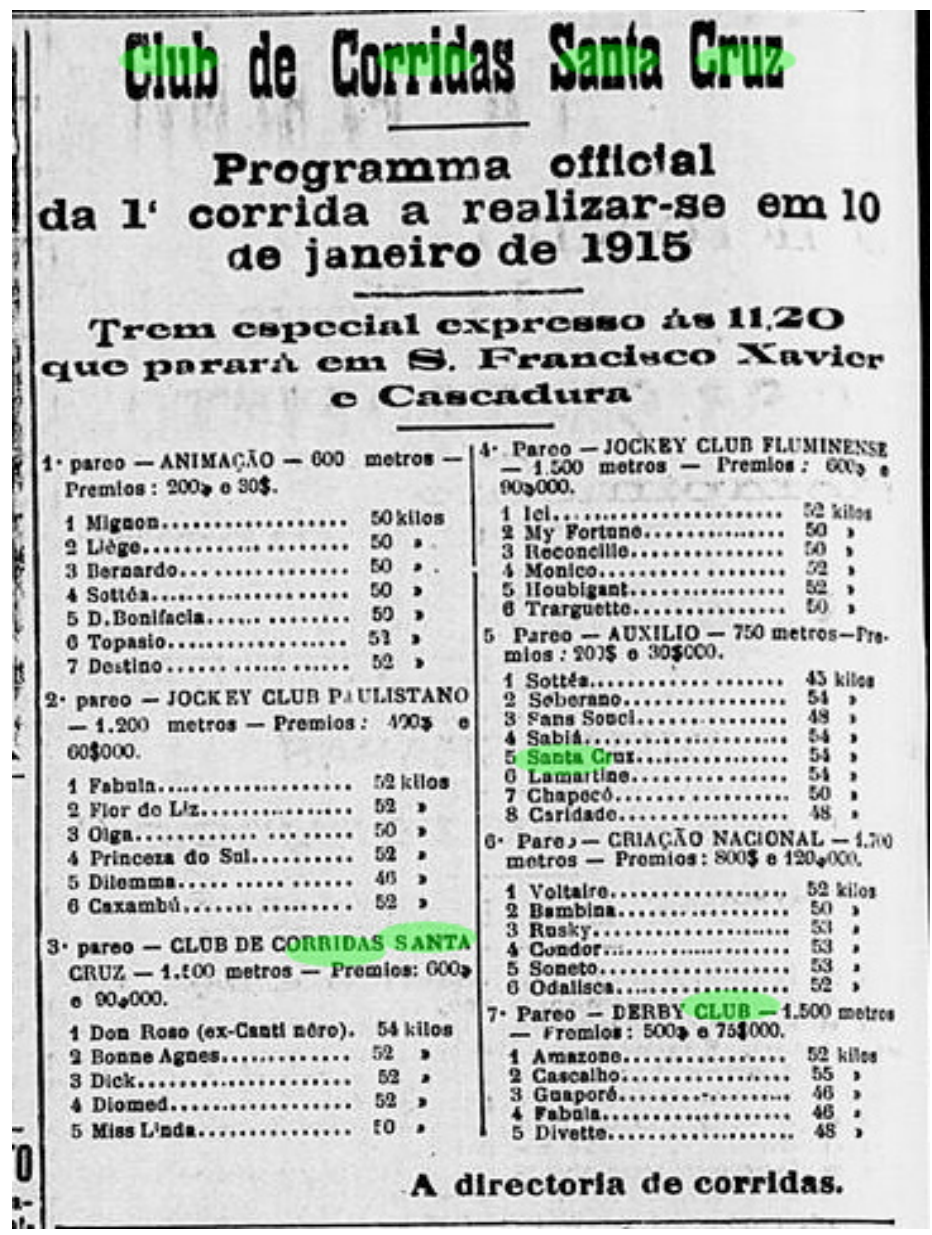

Figura 8. Programa de corridas. O Século, 9 jan. 1915, p. 4.

A despeito de críticas e restriçóes, o clube seguiu logrando popularidade, se constituindo em uma valorizada opção de lazer para o bairro e as redondezas. $\mathrm{Na}$ sessão inaugural de 1915, estiverem presentes cerca de 2.500 pessoas das "mais distintas famílias desta capital e da zona rural". ${ }^{83} \mathrm{Um}$ cronista sugeriu que em Santa Cruz "só se fala em corridas, o assunto é corridas entre os que vagueiam e fazem pontos nos cafés e botequins, e os que mourejam na luta pela vida; até nos lares, entre as famílias (...)" ${ }^{84}$

Tratou-se de mais uma temporada marcada por sucessos. A questão a responder era quanto tempo o Club de Corridas manter-se-ia superando as limitaçóes estabelecidas. Uma observaçáo de um cronista pode funcionar como um prognóstico. No seu olhar, "ao pitoresco hipódromo de Santa Cruz nada lhe falta para que em pouco tempo progrida e possa

\footnotetext{
${ }^{83}$ O Pais, 11 jan. 1915 , p. 5.

${ }^{84}$ Jornal do Brasil, 9 jan. 1915, p. 3.
} 
competir com as nossas melhores sociedades". ${ }^{85}$ Desconfiava, contudo, que muitas seriam as dificuldades para que essa possibilidade se materializasse.

Depois do sucesso das temporadas de 1914 e 1915, tudo parecia preparado para mais um bom resultado em 1916. Uma nova diretoria conduziria os caminhos da agremiação. Assumiu a presidência Jorge Larrhue, comerciante. Como secretário, foi eleito o já citado Olympio Pimentel. Também integraram a direção o coronel e criador de cavalos José de Lacerda Novaes, o sargento Tancredo Guerra Pires, o veterinário do Matadouro João Gualberto do Amaral. Seguia sendo gente de liderança em Santa Cruz, mas há que se reconhecer que de menor expressão.

O problema é que se acentuou a dificuldade de conseguir bons cavalos e jóqueis para que fossem oferecidos programas de qualidade. Um cronista, percebendo os esforços da diretoria, conclamou os criadores a inscreverem seus "animais de sangue" ${ }^{86} \mathrm{O}$ apelo não foi atendido. Houve muitas lacunas nas corridas, ${ }^{87}$ diminuiu o público, caiu o movimento de apostas. Em 1917, sequer houve a temporada e qualquer prova.

Para tentar recuperar o pleno funcionamento do clube, assumiram a direção personagens reconhecidos no bairro. Ernesto Durisch se tornou presidente de um grupo que tinha até mesmo Honório Pimentel como um dos dirigentes. Outra personalidade passou a auxiliar a agremiação, Raul de Carvalho, diretor do prestigiado Centro de Cronistas Esportivos, uma das principais lideranças esportivas do Brasil.

As expectativas não eram as melhores. Aventou-se a ideia de desistir de atrair os melhores animais e jóqueis. A expectativa mais otimista era contar com "os parelheiros perdedores (...) concorrentes dos dois prados do Rio". ${ }^{88}$ De toda maneira, na prova inaugural da temporada de 1918, o "prado campesino encheu-se totalmente, tendo havido apreciável movimento de apostas, que subiram a 14:943\$000". ${ }^{89}$ As atividades continuavam a ser prestigiadas pela populaçáo local e pelos adeptos que compareciam aproveitando os trens especiais.

\footnotetext{
${ }^{85}$ O País, 13 mar. 1914, p. 11.

${ }^{86}$ O País, 12 fez. 1916, p. 6.

${ }^{87}$ Para minimizar o problema de programas pouco atraentes, foram promovidas algumas provas de equitação, disputadas por oficiais do 1ำ Regimento de Cavalaria.

${ }^{88}$ A Noite, 3 jan. 1918, p. 7.

${ }^{89}$ A Noite, 21 jan. 1918, p. 5.
} 


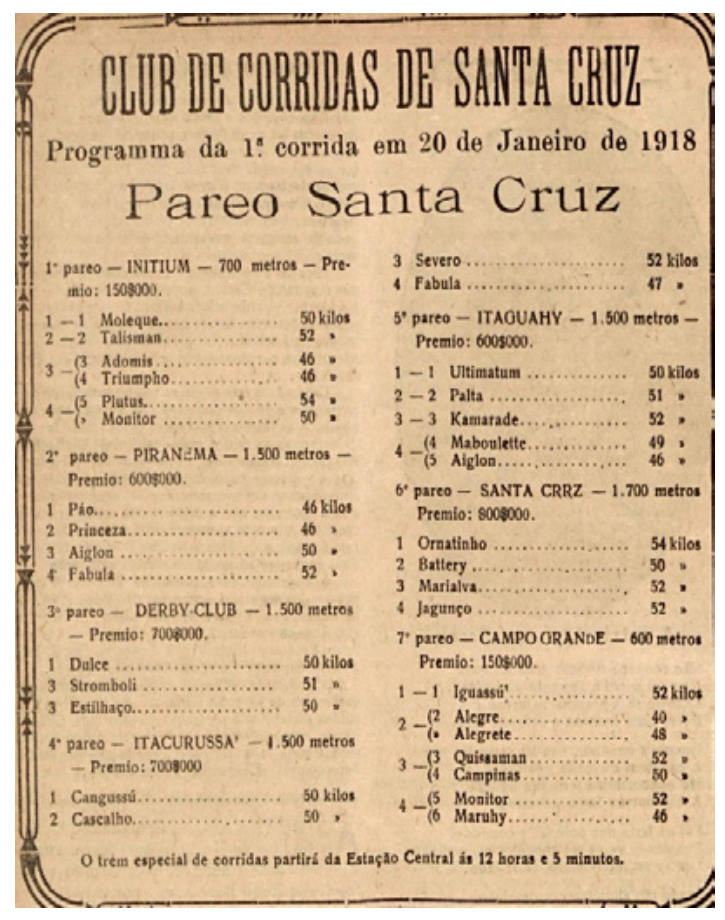

Figura 9. Programa de corrida. Teatro e Esporte, 19 jan. 1918, p. 16.

A despeito dos bons resultados, pareciam insuperáveis as dificuldades de compor um programa atraente em função da carência de inscriçôes e ausência de inscritos nos dias de corridas. Para um cronista, a agremiaçáo continuava tendo que enfrentar uma velha conhecida, a "má vontade de alguns proprietários". ${ }^{90}$ Para ele, eram inaceitáveis as exigências dos donos de cavalos, "tratadores, jóqueis e uma infinidade de interessados que nos dias de inscrição" apresentam "indicaçôes, lembrando conveniências, exigindo vantagens" ${ }^{91}$ Outro periodista sugeriu que "os responsáveis pelas coudelarias cariocas têm sido de uma incompreensível injustiça para com o prado de Santa Cruz". ${ }^{92}$ Mesmo com sucesso de público, tais restrições, bem como os gastos elevados, colocavam em xeque a manutenção do clube.

Além das dificuldades de oferecer bons programas, uma decorrência desse velho problema reapareceu: "Nada porém pudemos apurar quanto à veracidade das alegaçóes, e mesmo quanto aos páreos em que os arranjos teriam lugar. Entretanto, não se fez necessária grande perspicácia para descobrir-se o manejo dos poucos escrupulosos." ${ }^{33}$ Os tribofes tomaram conta do hipódromo, "o efeito moral foi desastroso". ${ }^{44}$ Fixara-se sobre o prado a ideia de que "amaxixou-se", tornou-se uma bagunça..$^{95}$

\footnotetext{
${ }^{90}$ Teatro e Esporte, 26 jan. 1918, p. 17.

${ }^{91}$ Teatro e Esporte, 16 fev. 1918, p. 8.

${ }^{92}$ A Noite, 20 fev. 1918, p. 5.

${ }_{93}$ Teatro e Esporte, 23 fev. 1918, p. 18.

${ }^{4}$ Teatro e Esporte, 23 fev. 1918, p. 18.

${ }^{95}$ Para mais informações sobre os tribofes, ver Lanterna, 4 mar. 1918, p. 4.
} 


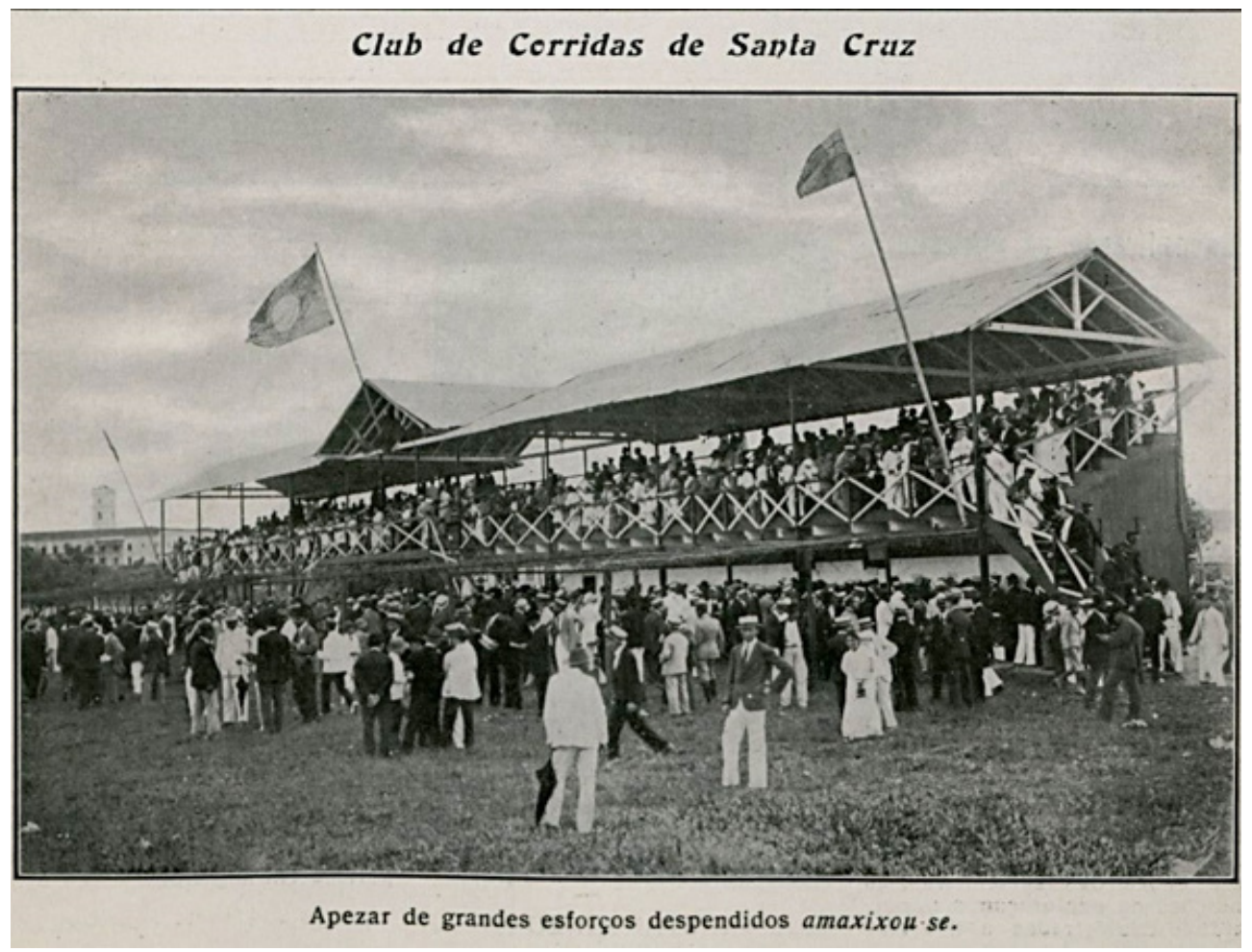

Figura 10. Careta, 23 mar. 1918

Depois de três sessóes marcadas por conflitos, ainda foram promovidas algumas corridas somente com animais locais, ocasióes que tiveram pouca repercussão na imprensa. Após anos tentando manter ativo o Club de Corridas Santa Cruz, a diretoria se deu por vencida. Em 31 de março de 1918, se realizou sua última prova. Encerrava-se a trajetória da agremiação turfística suburbana.

\section{Conclusão}

O cronista de O País, ao fazer uma análise da temporada de 1918, fez questão de mencionar o caso do Club de Corridas Santa Cruz, "que esforçando-se tanto quanto pode para realizar corridas no primeiro trimestre deste ano apenas conseguiu levar a efeito três meetings hípicos, ${ }^{96}$ isso mesmo com grande prejuízo pecuniário e com notável pertinácia e sacrifício". ${ }^{77}$ Sem citar os responsáveis, deixou entrever sua crítica: "É necessário, é indispensável, que haja harmonia e coesão entre os proprietários e as diretorias de corridas."

O que identifica o cronista é um desdobramento do processo de monopolização das práticas turfísticas encaminhado pelo Jockey e pelo Derby. Essas agremiaçóes, ainda que no discurso

\footnotetext{
${ }^{96}$ Perceba-se que o cronista sequer levou em conta as outras corridas promovidas na temporada.

${ }^{97}$ O Pais, 14 abr. 1918, p. 11.
} 
declarassem estar interessadas no desenvolvimento do turfe nacional, de diferentes formas e com distintas ênfases procuravam não facilitar o funcionamento de outras sociedades. $\mathrm{O}$ Club de Corridas enfrentou essas ocorrências, especialmente no que tange à inscrição de cavalos e jóqueis.

Nem sempre as intervençôes dos "clubes fidalgos" eram explícitas, até porque havia alguma convivência. Por vezes, diretores do Derby e do Jockey estiveram nas atividades de Santa Cruz. Em algumas ocasiôes, partilharam eventos em comum do meio turfístico. Havia mesmo certo trânsito de cavalos, jóqueis e treinadores. Náo poucas vezes, as agremiaçóes mais antigas foram homenageadas pela sociedade suburbana. Além disso, há que se ter em conta que as lideranças do arrabalde eram também gente de importância na cidade, que tinha acesso a diferentes esferas de poder. As restriçóes impostas, assim, faziam efeito no decorrer do tempo.

Cercou a trajetória do Club de Corridas Santa Cruz outra ocorrência, por vezes explícita, em outras nem tanto - certas representaçôes por ser uma agremiaçáo suburbana. Mesmo com todos os esforços da diretoria - uma elite local que procurou o reconhecimento da imprensa e das sociedades turfísticas mais tradicionais - eram constantemente enfatizados, em alguns ocasióes com olhar estigmatizado, os problemas do prado, alguns dos quais em parte ocasionados pelas próprias restrições estabelecidas.

A imprensa desempenhou um papel mediador. Em muitos casos, demonstrou simpatia com as iniciativas da agremiação suburbana, mas também, com frequência, a criticou de maneira exagerada e hierarquizada. Quando fazia o mesmo com o Derby e o Jockey, não era com o mesmo vigor. Com isso, acabou por contribuir com o forjar de estigmas que arranharam a imagem do prado: calorento, confuso, de qualidade inferior, conflituoso, "amaxixado". Vejamos como Ferreira, em breve artigo sobre a trajetória do turfe no Brasil, se referiu ao Club de Corridas, o comparando ao Prado Guarany:

Há mais ou menos uns 8 anos foi fundado em Santa Cruz um prado. Era um pouco melhor do que o da Vila Guarany. Não se consta que lá se fizessem os escandalosos tribofes que se registraram no prado da Praia Formosa. Mas a lisura não presidia sempre a disputa dos páreos apesar da energia de seus diretores. ${ }^{98}$

Ao citar o Jockey e o Derby, o autor não fez observaçóes negativas, ainda que nessas agremiações também houvesse tribofes e "problemas de lisura". De toda maneira, não se pode dizer que a agremiaçáo de Santa Cruz tenha fechado as portas somente por causa dos preconceitos. Mas não se deve desprezar a influência dessas representaçóes, bem como sua articulação com as restriçóes estabelecidas pelas agremiaçôes antigas.

\footnotetext{
${ }^{98}$ FERREIRA, Simões. O turfe no Brasil. In: ANUÁRIO DO BRASIL. Livro de ouro comemorativo do centenário da independência do Brasil e da Exposição Internacional do Rio de Janeiro. Rio de Janeiro: Almanak Laemmert, 1923, p. 298-301, p. 299.
} 
O caso do Club de Corridas Santa Cruz ajuda-nos a lançar um olhar sobre o processo de urbanizaçáo do Rio de Janeiro porque nos permite perceber tanto o protagonismo de grupos que viviam nas periferias quanto os estigmas que se forjaram sobre o subúrbio. Diz-nos, portanto, algo sobre como as desigualdades foram se forjando na história da cidade dita maravilhosa.

\section{Fontes}

A Noite, 29 dez. 1914, p. 5.

A Noite, 3 jan. 1918, p. 7.

A Noite, 21 jan. 1918, p. 5.

A Noite, 20 fev. 1918, p. 5.

A Notícia, 30 e 31 mar. 1914, p. 3.

A Rua, 28 mar. 1915, p. 2.

Careta, 23 mar. 1918.

Coleção de Leis Municipais e vetos — 1897 a 1931.

Correio da Noite, 18 jan. 1915, p. 4.

Ilustração Brasileira, 16 fev. 1915, p. 83.

Jornal do Brasil, 15 out. 1912, p. 10.

Jornal do Brasil, 9 jan. 1915, p. 3.

Lanterna, 4 mar. 1918, p. 4.

O Imparcial, 7 dez. 1912, p. 6.

O Imparcial, 31 dez. 1912, p. 6.

O Imparcial, 17 jan. 1913, p. 7.

O Imparcial, 31 jan. 1913, p. 6.

O Imparcial, 3 fev. 1913, p. 7.

O Imparcial, 6 fev. 1913, p. 6.

O Imparcial, 19 mar. 1913, p. 6.

O Imparcial, 23 mar. 1913, p. 12.

O Imparcial, 21 mar. 1913, p. 8.

O Imparcial, 24 mar. 1913, p. 7.

O Imparcial, 29 mar. 1913, p. 6.

O Imparcial, 25 nov. 1913, p. 1. 
O Imparcial, 16 dez. 1914, p. 9.

O Imparcial, 25 dez. 1914, p. 7.

O Malho, 29 mar. 1913, p. 27.

O Pais, 16 jul. 1912, p. 8.

O Pais, 27 out. 1912, p. 9.

O País, 12 nov. 1912, p. 9.

O País, 17 nov. 1912, p. 9.

O País, 23 jan. 1913, p. 8.

$O$ País, 26 jan. 1913, p. 10.

O Pais, 30 jan. 1913, p. 10.

O Pais, 1 abr. 1913, p. 9.

O País, 19 jan. 1914, p. 7.

O Pais, 13 mar. 1914, p. 11.

O Pais, 4 jan. 1915, p. 5.

O Pais, 6 jan. 1915, p. 6.

O País, 11 jan. 1915, p. 5.

O Pais, 12 fez. 1916, p. 6.

O Pais, 14 abr. 1918, p. 11.

O Século, 26 out. 1912, p. 4.

O Século, 19 dez. 1914, p. 2.

O Século, 9 jan. 1915, p. 4.

População, superfície e densidade territorial do Rio de Janeiro (Distrito Federal) com o crescimento médio anual (1906-1912). Disponível em: <https://seculoxx.ibge.gov.br/populacionaissociais-politicas-e-culturais/busca-por-temas/populacao.html>. Acesso em: 6 nov. 2017.

Teatro e Esporte, 19 jan. 1918, p. 16.

Teatro e Esporte, 26 jan. 1918, p. 17.

Teatro e Esporte, 16 fev. 1918, p. 8.

Teatro e Esporte, 23 fev. 1918, p. 18.

Teatro e Esporte, 23 fev. 1918, p. 18. 


\section{Referências bibliográficas}

ABREU, Maurício de Almeida. A evolução urbana do Rio de Janeiro. Rio de Janeiro: IplanRio/ Zahar, 2011.

ENGEMANN, Carlos; AMANTINO, Maria. Santa Cruz: de legado dos jesuítas a pérola da Coroa. Rio de Janeiro: Eduerj, 2013.

FERNANDES, Nelson da Nobrega. O rapto ideológico da categoria subúrbio. Rio de Janeiro: UFRJ, 1995.

FERREIRA, Simóes. O turfe no Brasil. In: ANUÁRIO DO BRASIL. Livro de ouro comemorativo do centenário da independência do Brasil e da Exposiçâo Internacional do Rio de Janeiro. Rio de Janeiro: Almanak Laemmert, 1923, p. 298-301.

FONSECA, Vitor Manoel Marques da. No gozo dos direitos civis: associativismo no Rio de Janeiro, 1903-1916. Niterói: Muiraquitá, 2008.

FREITAS, Benedicto. Santa Cruz. Fazenda jesuítica, real e imperial. Rio de Janeiro: Asa Artes Gráficas, 1985.

FRIDMAN, Fania. De chão religioso a terra privada: o caso da Fazenda de Santa Cruz. Cadernos IPPUR/UFRJ, Rio de Janeiro, v. 16, n. 1, p. 311-343, 2002.

LUCA, Tânia Regina de. História dos, nos e por meio dos periódicos. In: PINSKY, Carla Bassanezi (Org.). Fontes históricas. São Paulo: Contexto, 2005, p. 111-153.

MELO, Victor Andrade de. Cidade sportiva: primórdios do esporte no Rio de Janeiro. Rio de Janeiro: Relume Dumará/Faperj, 2001.

(Org.). Os sports e as cidades brasileiras: transição dos séculos XIX e XX. Rio de Janeiro: Apicuri/Faperj, 2010.

- Antes do club: as primeiras experiências esportivas na capital do Império (1825-1851). Projeto História, Sáo Paulo, v. 49, p. 197-236, abr. 2014.

. Rio esportivo. Rio de Janeiro: Casa da Palavra, 2015.

. O sport em transição: Rio de Janeiro, 1851-1868. Movimento, Porto Alegre, v. 21, n. 2, p. 363-376, 2015.

. Entre a elite e o povo: o sport no Rio de Janeiro do século XIX (1851-1857). Tempo, Niterói, v. 20, n. 37, p. 1-22, 2015.

MELO, Victor Andrade de; PERES, Fabio de Faria. Esporte e modernidade: o caso do Rio de Janeiro - uma abordagem panorâmica. In: MELO, Victor Andrade (Org.). O esporte no cenário Ibero-Americano. Rio de Janeiro: 7 Letras, 2015, p. 53-69.

2016. . Primórdios do esporte no Brasil — Rio de Janeiro. Manaus: Reggo Ediçóes, 
MELO, Victor Andrade de; SANTOS JUNIOR, Nei Jorge. O esporte nos arrabaldes do Rio de Janeiro: o cricket em Bangu (1904-1912). Movimento, Porto Alegre, 2018. No prelo. MENDONÇA, Leandro Climaco. Nas margens: experiências de suburbanos com periodismo no Rio de Janeiro, 1880-1920. Dissertação (Mestrado em História) — Programa de Pós-graduação em História, Universidade Federal Fluminense, Niterói, 2011.

MORAES, Edite. Os donos da Fazenda de Santa Cruz: uma breve história fundiária. In: ANPUH (Org.). Anais do XXIX Simpósio Nacional de História. Brasília: Anpuh, 2017.

OLIVEIRA, Igor Estevam Santos de. "E dançaram a noite toda, até a manhá...”: um estudo sobre o funcionamento das sociedades recreativas, carnavalescas e clubes na capital fluminense (1908-1913). Trilhas da História, Três Lagoas, v. 3, n. 5, p. 116-137, jul./dez. 2013.

OLIVEIRA, Márcio Pińon de; FERNANDES, Nelson da Nobrega (Org.). 150 anos de subúrbio carioca. Rio de Janeiro: Lamparina/Eduff/Faperj, 2010.

PEREIRA, Juliana da Conceição. A presença feminina nas associaçóes recreativas cariocas (1900-1910). In: ANPUH (Org.). Anais do XXIX Simpósio Nacional de História. Brasília: Anpuh, 2017.

SANTOS, João Manuel Casquinha Malaia. Economia do entretenimento: o processo de monopolização do primeiro empreendimento esportivo no Brasil (1850-1930). Economia e Desenvolvimento, Santa Maria, v. 27, n. 1, p. 202-222, jan./jul. 2015.

SANTOS, João Manuel Casquinha Malaia; GIGLIO, Sérgio Settani. O papel da memória na construção da identidade organizacional: a Sociedade Jockey Club (1868-1932) e o "desenvolvimento da riqueza pastoril". Recorde: Revista de História do Esporte, Rio de Janeiro, v. 10, n. 1, p. 1-21, jan./jun. 2017.

SANTOS JUNIOR, Nei Jorge. A construção do sentimento local: o futebol nos arrabaldes de Andaraí e Bangu (1914-1923). Dissertação (Mestrado em História Comparada) Programa de Pós-graduação em História Comparada, Universidade Federal do Rio de Janeiro, Rio de Janeiro, 2012.

. O turfsuburbano: o Club de Corridas Santa Cruz. História(s) do Sport (blog), Rio de Janeiro, 7 set. 1915. Disponível em: <https://historiadoesporte.wordpress.com/2015/09/07/ o-turf-suburbano-o-club-de-corridas-santa-cruz/>. Acesso em: 4 nov. 2017.

. A vida divertida suburbana: representaçóes, identidades e tensóes em um arrabalde chamado Bangu (1895-1929). Tese (Doutorado em Lazer) — Programa de Pós-graduação em Estudos de Lazer, Universidade Federal de Minas Gerais, Belo Horizonte, 2017.

SOUZA, Antonio Nascimento. Memória e história politica de Santa Cruz. Rio de Janeiro: Instituto Municipal de Arte e Cultura — Rio Arte, 2005. 